\title{
Neighbourhoods in the Lead: Grassroots Planning for Social Transformation in Post-Katrina New Orleans?
}

CLARA IRAZABAL \& JASON NEVILLE

\section{Introduction}

Since August 2005 when levee failures after hurricane Katrina destroyed $80 \%$ of the city of New Orleans, popular media and local residents alike have frequently used the term 'citizens' revolution' to describe the autonomous grassroots planning process in the post-Katrina city (Nossiter, 2006). Although the phenomenon of grassroots participation has been generally regarded as unprecedented in the history of the city, and perhaps even the nation, there has been no investigation of the extent to which a 'citizen's revolution' is truly underway. In the absence of effective leadership from the local, state and national level, residents have initiated their own planning efforts to restore and repopulate their neighbourhoods. Whether pooling resources to hire professional planners, or developing the plans themselves, many residents have initiated an autonomous, grassroots, citywide planning process that has involved hundreds of communities and has taken place almost entirely outside the purview of government and market sector support. As one resident of the devastated Broodmoor neighbourhood said, "There has been no direction given, so neighborhoods have to fend for themselves. We're on our own' (Warner, 2006).

Prior to the hurricane, the history of planning in the city - like many other political processes in New Orleans - had been underfunded, understaffed and largely undemocratic. However, in the decade before Katrina, a renewed interest in participatory community planning was beginning to gain some traction (Bureau of Government Research [BGR], 2003). Yet the unprecedented surge since Katrina in neighbourhood-based planning, which has taken place across racial, class and geographic lines, is being acknowledged as truly a historic moment in the city by local planners, officials and residents (Andersen, 2006b; Baricos, 2006; Villavaso, 2006).

This article places these neighbourhood planning processes in a historical and socio-political context and trajectory that illuminates their scope and significance, as well as the prospects of a possible shift to broader and 
more transformative political processes in New Orleans. The article offers insights about the potential for broader democratic transformation in post-Katrina New Orleans vis-a'-vis this autonomous grassroots planning process, surveying some of these neighbourhood-based processes (to the extent possible, considering their ongoing nature). Our point of departure is the acknowledgement that, in the absence of an effective governing coalition capable of creating stability and a political mandate for effective planning, the onus of planning has, to a great extent, been relegated to, or taken over by, the communities themselves. In this context, the widespread 'taste' of autonomous democratic place-making could trigger a wider sociopolitical transformation, resulting in a paradigm shift at other levels of the political process including grassroots activism, electoral reform, regional governance, sustainable economic development and equity planning. That is, residents working to create a community-based participatory planning process might - intentionally or otherwise - parlay that sense of empowerment into a movement to create a communitybased participatory political culture that transcends the reconstruction efforts altogether. We contend that the restoration of the social networks of New Orleans is a critical factor in allowing the grassroots planning to continue, expand, and develop a resilient and community-based planning culture that serves the purpose of recovery and beyond.

We use the notions of active citizenship, insurgent citizenship, invented spaces of citizenship, covert planning and other emancipatory theoretical frameworks to contextualize the planning processes in both pre-and postKatrina New Orleans. In doing so, we pay special attention to comparisons with recovery planning in so-called 'developing' nations, illuminating what we think is a better context for understanding recovery, democracy and civil society in New Orleans. Lastly, prospects for democratic planning in New Orleans and beyond are discussed, along with recommendations for planners and policy-makers. Our research methods include several years of involvement in formal and informal planning processes in New Orleans, as well as four surveying visits to post-Katrina New Orleans; two semesters' worth of graduate-level urban laboratory classes; ongoing communication with residents and planners; and a two-week field visit which included participant observation, observation, semi-structured interviews and physical surveys.

\section{Overview of Planning in Pre-Katrina New Orleans}

Before hurricane Katrina hit the Gulf Coast in August 2005, New Orleans was a city of net population loss, losing $30.3 \%$ of its population since its 1960 peak of 627,525 and grappling with enormous and seemingly insurmountable problems of poverty, substandard education, corruption and unemployment (Gibson, 1998; US Census, 2005). The apparently 
hopeless economic situation fostered a 'development-at-any-cost' business climate heartened by pliant city and state governments, which were all too eager to approve virtually any project that would create any tax revenues or job gains. This was frequently done regardless of longterm benefits or wage levels, particularly those in the exploding povertywage tourist industry (Gotham, 2005). Adding to the collective hopelessness was a 'discouraging' and 'incoherent' planning process that was 'symptomatic of systemic weakness' and leading 'ineluctably to cynicism and disengagement among the citizenry' (BGR, 2003; American Planning Association [APA], 2005). Even pro-growth boosters, such as business executive-turned-reformer mayor Ray Nagin, viewed the overall planning process - which was as equally convoluted to developers as to residents - as 'part of a larger, dysfunctional system that hinders economic growth' (BGR, 2003). Widespread and bitter perceptions by neighbourhood associations and political observers that developers had already received surreptitious consent from the Council members in whose district the projects were slated were constant reminders of the cronyism that all too often replaced best planning practices and the public interest in New Orleans (BGR, 2003).

To allow specific communities to take a more proactive role in determining their own planning agenda, the Planning Commission began in the late 1990s to allow and encourage communities to create their own 'Renaissance Plans' (similar to California's 'specific plans') that could be incorporated into the Master Plan. One consultant working on one of the pre-Katrina Renaissance Plans described them (to a packed audience of neighbourhood residents and business owners) as a process that 'enables residents of these neighborhoods to take a more active role in the city planning process with regard to revitalizing their neighborhoods' (Miller, 2001). Yet only two neighbourhoods - Lower Garden District and New Orleans East (itself a giant area much larger than a typical neighbourhood) - ever developed Renaissance Plans for their communities.

In addition to neighbourhood-generated planning designed to incorporate better citizen participation in the overall planning process, frustrated civic leaders established in 2000 a broad-based and privately financed organization to develop a plan for the city's housing, transportation, economic development, city management/finance, education and public safety. The group included the presidents of eight local colleges and universities and a council of religious leaders as advisors (Eggler, 2000b). With an initial budget of $\$ 350,000$, the Committee for a Better New Orleans (CBNO) set to work on its 'Blueprint for a Better New Orleans', a plan with quantifiable goals for the city, as the City Planning Commission struggled to move its Comprehensive Zoning Ordinance forward (Young, 
2001). Making sure people understood the import of his organization's book-length document, CBNO Chairman and multimillionaire developer Joe Cannizzaro ${ }^{1}$ stated about the Blueprint: 'It's not a study, it's a plan' (Eggler, 2000a).

Although much more limited in scope than the City's Master Plan, the Alist roster of civic leaders arguably produced a higher-profile plan than the City's own, and generated significant enthusiasm from city boosters. The CBNO even stepped into the official process in 2003 to halt the approval of the Transportation Element of the Master Plan, concerned with its lack of citizen participation and overall weakness. As Keith Twitchell, President of CBNO, said:

It was disjointed, poorly written, [with] very little vision, [and] very little connection between various transportation pieces. When we explored this a little bit, it turns out that they wrote the element without consulting any of the transit agencies.... CBNO proposed that we get the agencies together to turn it into something decent. We were concerned about the minimalist public participation plan. ... The CPC created a new draft that was markedly improved, because this time it actually had [stakeholder] input. There was a lot of public comment; we even took on the responsibility of writing up the public comments. (Twitchell, 2006).

The CBNO even launched a special initiative to get a formal citizen participation mechanism into the city charter. But as CBNO leader Keith Twitchell told us in a post-Katrina interview, 'Even if all Council members vote for it [the proposed Citizen Participation Element of the Master Plan], there's this question of how "participatory" it really is if it's mandated from the top and trickles down from there. We wanted to start in the neighbourhoods and formalize it from there' (2006, our emphasis).

On the eve of Hurricane Katrina, the City Planning Commission maintained its modest efforts to increase participation in their Riverfront Vision Plan that outlined redevelopment for the mostly defunct warehousing space that lined both east and west banks of the Mississippi River. The process included an invitation-only American Institute of Architects-co-sponsored charette with architects, designers and institutional/community stakeholders such as the Convention Center, Audubon Institute and neighbourhood groups (east bank only) to begin a visioning process followed by a series of public workshops. Knowing that there were a handful of key issues that the community was already concerned about, the CPC 'worked hard to get participation [from the community] and invited developers too to make cohesive plans' to pre- 
empt as many conflicts as possible before releasing the plan (Winkert, 2006).

In pre-Katrina New Orleans, formal planning lacked any cohesive, long term governing coalition, instead relying on short-lived, issue-based coalitions that 'prevent[ed] stakeholders from either reaching shared understandings of policy problems and solutions, or recognizing and forming a larger, more systemic community agenda' (Burns and Thomas, 2006). Combined with a struggling economy, an emasculated Planning Department, and weak formal citizen participation, the extant planning culture was part of a larger and dysfunctional governance structure that, by neglect, had already placed the de facto onus for community planning efforts on the residents and neighbourhoods themselves, even before the hurricane hit the city (BGR, 2003; APA, 2005; Foley and Lauria, 2000).

\section{Active Citizenship in Pre-Katrina New Orleans}

In both developing and developed nations, marginalized and impoverished communities often create autonomous spaces of citizenship to establish (or reclaim) an active role in civil society. This may take the form of direct, politically conscientious activism intended to transform society along specific ideological lines, such as the Zapatistas in Chiapas or the Bus Riders Union in Los Angeles, which work to enact a conscious political agenda (Grengs, 2002). But active citizenship may also be more subtle, nuanced and nascent - though still powerful and potentially socially transformative. Left in the social and political margins, and without access to the formal institutions provided by the state, disenfranchised residents may work to create their own notions of 'citizenship' or to engage in their own autonomous planning processes to achieve social and political gains. The term 'invented citizenship' is used in contrast the 'invited' spaces of citizenship in which the state defines the terms of citizenship for its citizens. This new 'citizenship from below' (Miraftab \& Wills, 2005, p. 202) is a tactic for disadvantaged communities to 'create their own opportunities and terms of engagement' (Cornwall, 2002, p. 50). In their study of 'insurgent planning' by residents (mostly women) of a poor black township in South Africa to stop residential evictions, Miraftab and Wills (2005, p. 201) write: 
As opposed to a statist citizenship that assumes the state as 'the only legitimate source of citizenship rights, meanings and practices' (Holston 1998, 39), this alternative drama of citizenship is active, engaged, and 'grounded in civil society' (Friedmann 2002, 76). It moves beyond formal citizenship to a substantive one that concerns an array of civil, political, social, and economic rights, including the rights to shelter, clean water, sewage discharge, education, and basic health - in short, the right to the city (Lefevbre 1996).

Active citizenship can take the form of more direct practices described as 'insurgent citizenship' or 'insurgent planning', which not only seek to reclaim notions of citizenship but to actively agitate for social and political gains - a strategy 'employed by the poor to hold city officials accountable to their civil and political rights' (Miraftab \& Wills, 2005, p. 202). While insurgent planning can be a powerful tool of emancipatory planning practices, many communities are often confronted with violent or openly antidemocratic political conditions that restrict the levels of overt challenge to state authority. Often times, however, communities in restrictive environments autonomously plan for social transformation (Beard, 2002). This 'more covert, incipient, and incremental form of planning', dubbed covert planning, attempts to address some of the gaps in radical and insurgent planning literature (p. 16). In this scenario, communities that might otherwise engage in directly transformative planning practices might be prevented from doing so due to open hostility of authoritarian regimes, as was the situation in Beard's study of a grassroots development of a community library in Indonesia. Beard also posed a challenge to further enhance the concept of covert planning . . . [in contexts such as] highly disadvantaged communities that exist in liberal democratic settings' (p. 24). We address this challenge by deploying covert planning's analytical power on the marginalized community planning cultures in pre-Katrina New Orleans.

In that regard, we look at some of the insurgent street activities in working-class black neighbourhoods of antediluvian New Orleans to excavate precedents for the community-based planning efforts underway in post-Katrina New Orleans, employing the 'situated practices of citizens [and] moving away from the notion of an expert and scientific knowledge [of planning] to an ethnographic one' (Holston, 1999, p. 158) to demonstrate pre-Katrina active citizenship that could now become the basis for more socially transformative planning. Neighbourhood planning, like other sociopolitical processes in New Orleans, has been characterized by disenfranchisement, class/race polarization, bourgeois preservationism, elite corruption and 'neighborhood localism' (BGR, 2003; APA, 2005, Foley \& Lauria, 2000; Laska \& Spain, 1979, p. 529). The 
marginalization of neighbourhood groups and low-income communities provided the context for residents in pre-Katrina New Orleans to begin to autonomously create a valuable form of active, invented and covert processes of community identity formation and control.

Though participation in the formal planning process has been stymied by an underresourced Planning Department, ${ }^{2}$ a pliant City Council, and a vacuum of political leadership, neighbourhood planning occurs nonetheless, albeit in a more informal fashion. This is by no means a homogeneous process. While New Orleans is a city of residents who usually profess fervent loyalty to their neighbourhoods, this parochialism is expressed and organized in different ways, especially along lines of class and race (Warner, 1998). There is a fairly well-organized and informal community-building process that takes place mostly in the working-class and working-poor black neighbourhoods of New Orleans, which is distinctive from the more formal neighbourhood solidarities of affluent (and often 'whiter' communities), including middle-class black neighbourhoods (Regis, 2001). For instance, while many white and/or affluent newcomers to New Orleans' inner city neighbourhoods are highly involved in formal electoral politics and home-owners associations (Laska \& Spain, 1979), many African-American residents 'produce neighbourhoods' though insurgent street celebrations and the maintenance of dynamic and neighbourhood-based 'social aid' organizations, such as the Treme Sidewalk Steppers, the Double Nine High Steppers, The Moneywasters and the Happy House Social and Pleasure Club (Regis, 1999, 2001) (see Figures 1 and 2).

In New Orleans, the poorest neighbourhoods 'are transformed through traditional performances, such as second line parades, ${ }^{3}$ jazz funerals, and other impromptu street festivals' (Regis, 1999, p. 42), shaping their environments 'through resistance and insurgency' (Miraftab \& Wills, 2005, p. 201), and demonstrating the latent potentiality of a fuller democratization in New Orleans. While street celebrations are the most visible aspects of this self-organization, the social aid and pleasure clubs that host them are neighbourhood-based organizations that developed to provide social and financial assistance to neighbours in Jim-Crow ${ }^{4} \mathrm{New}$ Orleans (Breunlin \& Regis, 2006; Spitzer, 2006). In pre-Katrina New Orleans, these residents - excluded explicitly and implicitly from access to formal institutions such as banks and insurance agencies - relied on a dynamic, neighbourhood-based solidarity to create autonomous grassroots institutions to provide social and economic assistance to one another. These parades and social aid organizations 'continue to speak to the contemporary struggles of the city's majority black and working-class population ... and constitute a dream work of marginalized communities' 
(Breunlin \& Regis, 2006, p. 3). Indeed, most of the participants in these organizations 'are not "owners" of homes, real estate, or large public businesses. Yet through the transformative experiences of the parade, they become owners of the streets ... experiencing a transcendent power in this collective celebration' (Regis, 1999, p. 478). These second lines and social aid and pleasure clubs articulate 'the grassroots governance, social action and economy that are essential to organization in the black and Creole neighbourhoods ... The second line is the public artistic statement of the neighbourhood-the largest organic social unit of community and of political life in the city' (Spitzer, 2006). These informal reclamations of space and community are also affirmations of the 'right to the city' (Lefebvre, 1974 [1991]) and of larger political citizenship, suggesting a broader, more 'active' citizenship (Kearns, 1995; Miraftab \& Wills, 2005; Irazabal, 2008) in New Orleans that expands the traditional sociospatial sphere of citizenship and establishes a basis for broader democratization:

This new drama of citizenship is performed not only in the high courts of justice and ministerial corridors of government institutions but also in the streets of the city, the squatter camps of hope and despair, and the everyday lifespaces of those excluded from the state's citizenship project. (Miraftab \& Wills, 2005, pp. 201 - 202).

In contrast, formal planning processes often overlook 'the ways in which communities find meaning in where they live and where their families have lived for generations, and why the right of return [to previous neighbourhoods] has such special salience' (Pastor et al., 2006, p. 27). In pre-Katrina New Orleans, the active citizenship of informal mutual aid societies, along with the increasingly organized formal neighbourhood groups, provided a foundation for a more coordinated and effective neighbourhood planning process that has reemerged and restructured after the hurricane destroyed their neighbourhoods.

\section{After the Storm: Neighbourhoods and Community-based Organizations Take the Lead}

While formal pre-Katrina planning was stifled by weak governing coalitions incapable of providing effective leadership, the extreme disorganization of these efforts since Katrina has, paradoxically, created a de facto empowering of communities. This condition has opened previously unavailable opportunities to create - and more importantly, to implement, to a certain extent - the communities' visions for their neighbourhoods. To understand the extent of the circumstances in postKatrina New Orleans that created the conditions for grassroots planning to take the lead, it is helpful to briefly review the formal recovery planning 
processes led by state and local offices.



FIGURE 1. Nine Times Social and Pleasure Club parading in 2004 across the Florida Avenue canal on their way back to Desire after a four-hour parade through the 9th Ward (photo by Rachel Breunlin).

\section{Formal Planning Post-Katrina}

The first official planning effort was Mayor Ray Nagin's Bring New Orleans Back (BNOB) committee, which developed a plan for recovery with a series of proposals by committees ranging from education to transportation to culture. The most prominent of these was the Land Use Committee, due to anxieties among residents regarding the primary question before that committee: where exactly to rebuild (and not to rebuild). This committee's report featured professional consultation by the Urban Land Institute (ULI) and had little input from communities. Upon the unveiling of the Land Use Committee's recommendations, many neighbours were shocked and outraged to see large green dots where their neighbourhoods were - signifying that the BNOB plan was recommending the demolition of these areas and their conversion to floodable green spaces. The effects of the committee's recommendations triggered a flurry of planning efforts led by ordinary residents determined to bring their communities back, regardless of what the BNOB's closed-door committees were suggesting. 
FIGURE 2. Corey Woods of the Big Seven Social Aide and Pleasure Club parading with Rebirth Brass Band on the Almonaster Bridge in the 9th Ward (photo by Rachel Breunlin).

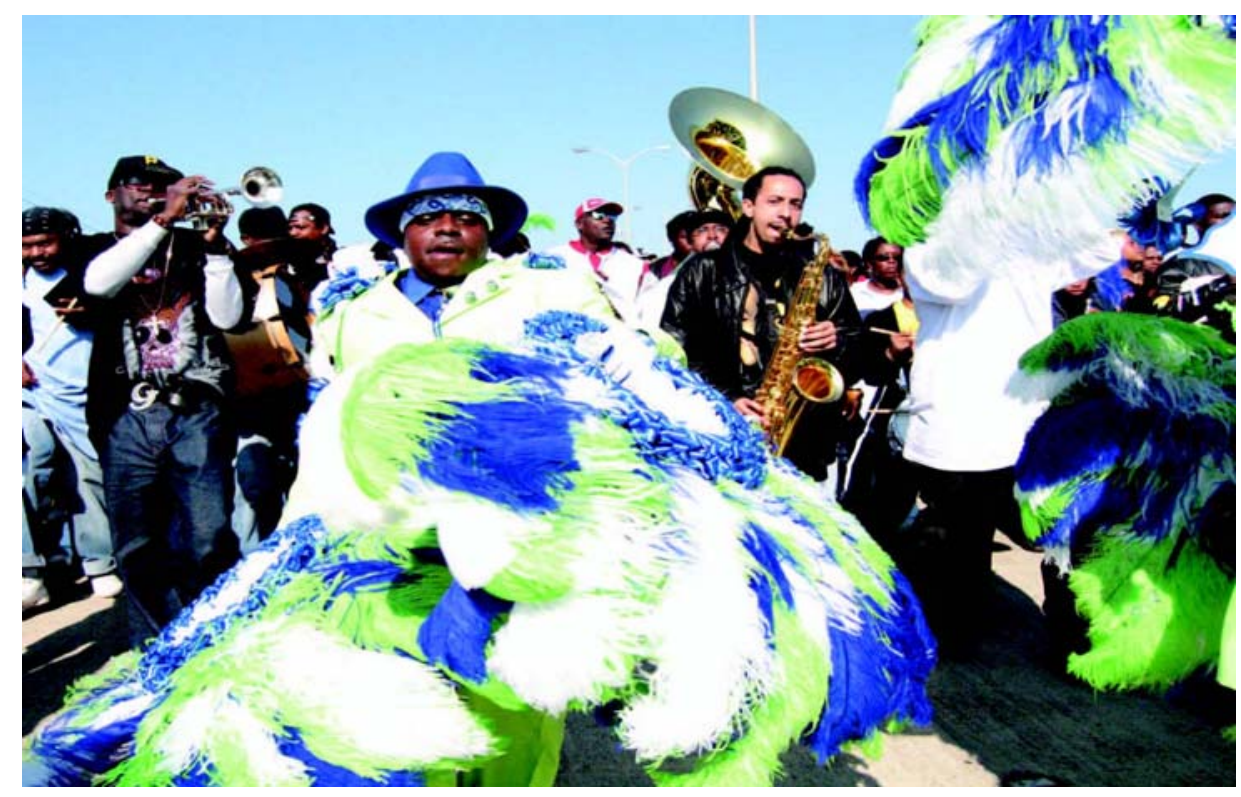

True to the dysfunctional tradition of New Orleans political fiefdoms, the New Orleans City Council then initiated a separate plan for rebuilding. Feeling sidelined and politically emasculated by the prominence of the Mayor's BNOB plan, the City Council voted to spend \$3 million dollars to hire a professional planner to develop plans for only the most-damaged neighbourhoods. Known colloquially as the 'Lambert Plan' (after the primary planning consultant in the effort), it wrapped up its efforts just as the 'Unified New Orleans Plan' (UNOP) became the new talk in the increasingly plan-weary town. Unlike the Lambert Plan, which only

covered certain 'wet' parts of the city, the UNOP effort was funded by the Rockefeller Foundation with an expressed mandate to create a citywide comprehensive plan to be the basis of federal funding for recovery projects. The UNOP plan hired 13 planning firms to work with neighbourhoods in each of the 13 planning districts of the city, as well as planners to develop a citywide infrastructure plan to link those 13 plans into one comprehensive plan. The firms worked directly with neighbours in the planning districts (even allowing the neighbourhoods to choose the firm with which they wanted to work) and presented their plan in January 2007. Though this plan ostensibly incorporates the neighbourhoods' own plans into its recommendations, the grassroots planning continues nonetheless; residents have little or no faith that the adopted plan will reflect and implement their vision for the city. Appointed by Mayor Nagin to lead the city's recovery efforts in December 
2006, veteran recovery planner Ed Blakely found himself in a city teeming with 'a patchwork of residents who had returned home bursting with ambition but lacking support to rebuild their neighbourhoods' (Krupa, 2007).

\section{Neighbourhoods Take the Lead}

As Steve Villavaso, the former Louisiana APA President and current toplevel UNOP planner, told us, 'Civic participation in New Orleans is at an all time high. Neighbourhood groups started planning in their neighbourhoods because there was no government after Katrina, or widespread confusion about other planning processes going on' (2006). Paul Baricos, director of a non-profit neighbourhood-based planning and housing organization in the city, also described to us the surge of autonomous neighbourhood planning as:

a great sign for participatory planning in New Orleans. There are scores of these [autonomous neighbourhood-based] meetings taking place across the city to do planning. It's a truly indigenous phenomenon. Much of it was a reaction to the Bring New Orleans Back committee's mandate that neighborhoods prove their own 'viability,' but it would've happened anyway. These groups all came together through the neighborhoods themselves. The City Planning Commission has had zero role. And the BNOB Committee said that they'd provide assistance, but it has yet to materialize. (Baricos, 2006, his emphasis).

Neighbourhood planning processes are taking place across civil society, from working-class progressive groups agitating for fundamental socioeconomic change, such as the People's Hurricane Relief Fund and Common Ground Collective, to more institutional forms such as HUD's Universities Rebuilding America Partnership, the Committee for a Better New Orleans, and the Tulane City Center's Urban/Build Consortium (see Figure 3). The Neighbourhoods Planning Network, an autonomous gathering of neighbourhood representatives, claimed in August 2006 that over 255 neighbourhood groups, 60 NGO/nonprofits, 30 churches, 30 media outlets, 40 universities, and your friends and neighbors' attend their weekly meetings (Neighborhoods Planning Network, 2006). 


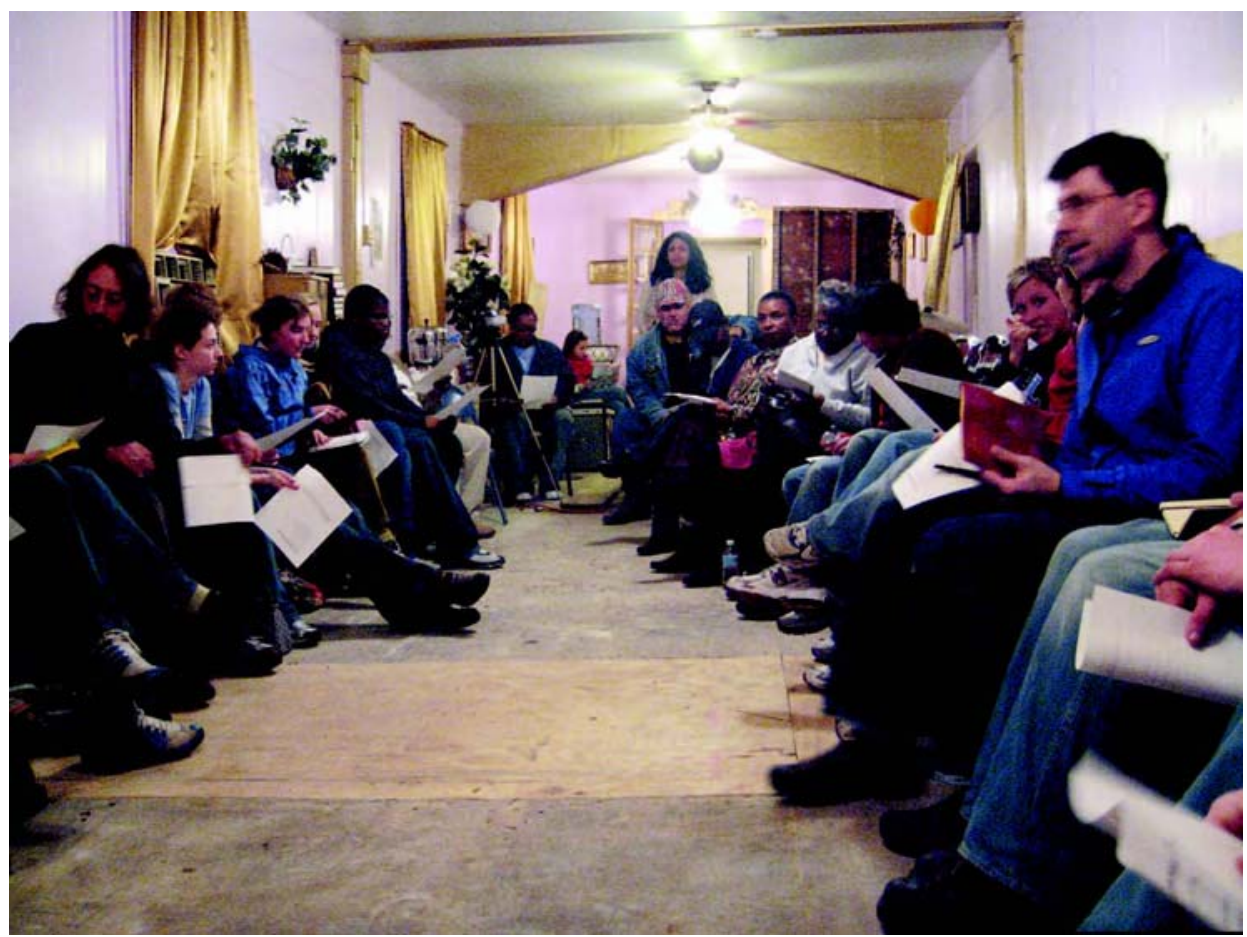

FIGURE 3. Porch cultural Organization meeting in the 7th Ward to discuss community design initiatives with the University of Kansas School of Architecture (photo by Rachel Breunlin).

Specific neighbourhoods and communities have initiated complete planning efforts that include professional planning assistance. For instance, the Vietnamese community in New Orleans East developed a community development plan that included resident surveys and proposals for an improved business district, linear parks along canals and a community housing development adjacent to the prominent Mary Queen of Vietnam Catholic Church (Mary Queen of Vietnam, 2006). The report was complete with plan and section view drawings of the proposed new districts, and was developed solely by the community with no support or coordination from the local, state, or federal governments. Like other neighbourhoods, the community's efforts were amplified by news from the Bring New Orleans Back Commission that their area was not necessarily going to be rebuilt, which 'seems to have exacerbated feelings of uncertainty among [community organizer] Tran and other residents of Vietnamese ancestry' (Williams, 2005). Rev. Vien Ngyuen, the leader of the Mary Queen of Vietnam Catholic Church, reacting to the news, said, 'We were never invited to the table ... we have the right to be part of the community-driven process' (Williams, 2005). In addition to becoming a relief centre and a community planning entity, the church also became 'one of the community's key political voices in opposing a new 88-acre 
landfill the city wants to open in eastern New Orleans' (Nolan, 2006a).

In the Broadmoor neighbourhood - an ethnically and economically diverse community located in some of the lowest elevations in the city recommendations by the BNOB to revert the neighbourhood to open space 'electrified a diverse group of homeowners who reached out to each other, determined to save their community'. They 'turned their once sleepy Broadmoor Improvement Association into a grassroots planning powerhouse' in which they 'conducted resident surveys, shared information on contractors, established a system of block captains, and began talking about how their neighborhood should be fixed' (Nolan, 2006b). The work of the Broadmoor neighbourhood to engage in their own planning efforts attracted the attention of Harvard's Kennedy School of Government to help craft a professional plan for the community, as well as a pledge from former President Bill Clinton's Global Initiative for $\$ 5$ million towards redevelopment efforts.

Grassroots religious institutions too have continued their collaborative neighbourhood-based leadership that had recently increased in power and offered African-Americans opportunities to participate in state and municipal politics (see Lang \& Danielsen, 2006). The most prominent of these in pre-Katrina New Orleans was All Congregations Together (ACT), a grassroots coalition of approximately 80 Jewish, Protestant and Catholic organizations, comprising around 100,000 members with a 'disciplined, church-based pursuit of grass-roots democracy' (LeGardeur, 1994; Nolan, 1994). Based on the work of Chicago's radical organizer Saul Alinsky, the group provided multiracial, multiclass venue for progressive communitybased planning and the inspiration for other similar religious coalitions to emerge (Nolan, 1994). A 1993 editorial by the TimesPicayune called ACT 'a grass-roots political force unlike anything seen before in New Orleans history' and mentioned that ACT's success in creating grassroots community development plans was 'remarkable' and was 'leading the leaders' (Times Picayune, 1993). Since Katrina, these faith-based organizations have assisted with social and medical service delivery, but have also focused on engaging residents and congregations into the planning process itself. For instance, ACT set up meetings to engage the religious faithful in the Bring New Orleans Back Commission and worked with local schools of architecture to develop neighbourhood plans for historically black neighbourhoods - plans that were anticipated to be completed before the BNOB's official plans were finished (Russell \& Donze, 2006). To New Orleanians struggling not only to rebuild, but to ensure their very survival, counting on state and private sector pledges is not guarantee enough. Activists across the city - 'including Broadmoor, eastern New Orleans, Lakeview and Gentilly - were cobbling together their own plans, fearing the worst if decisions were left to the power 
brokers' (Warner, 2006). Neighbourhoods have even taken to the task of preparing their own emergency preparedness plans, expecting that in a future catastrophe, there will be little or no assistance from local, state, or federal agencies (Simmons, 2006).

\section{Grassroots Recovery in Comparison: 'Developing' World Contexts}

To better understand the grassroots 'citizens' revolution' in New Orleans, we place these efforts in a sociopolitical context that includes a review of other types of autonomous community planning and reclamations of citizenship throughout the world. Interestingly, many of these examples come from the so-called third-world, versus the 'developed world' context in which New Orleans presumably exists.

The critical importance of placing the political, cultural, economic, and sociospatial order of New Orleans in such a developing context has begun to be elucidated by scholars since Katrina. As New Orleans-based folklorist Nick Spitzer writes,

In addition to the values of traditional cultures and the creation of a shared city/region cultural sensibility that transcends race and class in a manner more consistent with Latin-AfricanCaribbean societies than with the Anglo/African-American South, New Orleans and the surround suffers from many problems associated with so-called Third World societies. It has an old colonial legacy of overseas capitalism and slavery, manifest today in a highly inequitable social order topped by a small, mostly white elite-one not given to dynamic leadership promoting social and economic growth or a fully realized sense of 'public good.' The city's large, poor, mostly black and AfroCreole underclass faces huge problems of unemployment, nonliteracy, substance abuse and, most of all, exclusion from social advancement ... in this semi-feudalistic urban social order.

As a more practical implication of this situation of New Orleans in a 'developing world' context, Cuban-born architect Andres Duany has called for a building plan that would let certain areas of the city 'opt out' of the bureaucratized American planning process in which the state raises standards 'to the point where it is so costly and complicated to build that only the state can provide affordable housing' (Duany, 2007). He argues that it will only be possible to effectively rebuild the real New Orleans ethos when people can build their own houses-as many New Orleanians have done-section by section, generation by generation. He writes that, 
one way to [have] leisure time is to have a low financial carry. With a little work, a little help from the government, and a little help from family and friends, life could be good! This is a typically Caribbean social contract: not one to be understood as laziness or poverty - but as a way of life (ibid).

These linkages to learning from 'developing' countries elsewhere in the Caribbean-rim have begun to be forged by community activists in New Orleans. A contingent of progressive community leaders from the New Orleans Survivor's Committee recently traveled to Venezuela to learn from that country's consejos comunales (community councils) which are a part of the Venezuelan government's national planning strategy aiming to decentralize, democratize, and fund planning efforts at the neighborhood level (Iraza'bal and Foley, 2007). In a letter to the Venezuelan government on their website, the New Orleans Survivor Council writes that, '[i]n your communal councils, we see organizations similar to ours. Our goal is to empower the people at the bottom to begin to self-govern. You have a government that declares support for that process. We don't, and that is why we have come to you' (New Orleans Survivor Council, 2007).

While this New Orleans-developing world connection ought to be more critically explored, the following examples from community-based disaster recovery in 'developing nations' provide direct evidence to the power of effective grassroots mobilizations after disasters, and thus offer salient insights into the potential for social transformation in post-Katrina New Orleans.

Following a 1999 earthquake measuring 7.4 magnitude in Golcuk, Turkey, that damaged almost 250,000 residential and commercial units and killed 17,480 people, abysmal recovery assistance and planning by the government shattered the people's trust in the 'Father State', a governance structure characterized by a strong, centralized and elite government that 'ruled for the masses' rather than 'ruled by the masses' and fostered a weak civil society (Ganapati, 2005). Yet, this characterization was stripped and transformed as the deep incapacitation of the government became more obvious in the immediate aftermath; 'civil society rose to fill its void by playing an active role in the quake zone, gaining broader trust and respect' that was likened to a great 'awakening' of civil society (p. 280). Self-organized groups worked to not only provide immediate search and rescue efforts, but also to begin the process of delivering longer-term services such as medical, housing, food, clothing and financial aid. While some members of the government were appreciative of these groups' work, the reaction from the state was one of scepticism and at times open hostility. Sensing the potential for larger political agitation to emerge from such organized and democratic 
institution building, the state attempted to halt some of the activities by imposing strict measures on their operations, encouraging international aid to be channelled through state-controlled apparatus', and threatening lawsuits (p. 280). Significantly, Ganapati concludes that disasters can act as catalysts for rapid development and unleashing of dormant social capital.

In Mexico City, two back-to-back earthquakes in September 1985 measuring 8.1 and 7.5 on the Richter scale respectively - killed over 5,000 people, injured 14,000, and made 2 million homeless (hundreds of thousands permanently). It was the most extensive damage to the city since Cortez conquered it in 1521 when it was the ancient Aztec city of Tenochtitlan (Davis, 2005). 'Within days of the earthquake, people began to organize on their own and reclaim the city for themselves by taking over the business of recovery and reconstruction without assistance from government authorities' through such activities as housing and medical services delivery, and maintaining a strong vigilance for social justice and equality 'in direct contrast to the government's elitist approach. Most important, citizens' self-organization around recovery efforts in turn produced lasting changes in the politics of the city' (p. 270). Social activists such as housing advocates were successful in immediate postearthquake relief efforts as well as in the long term by coordinating new coalitions of citizens groups that made strong demands for social services and housing. They also 'served as a central political force in subsequent struggles for the democratic reform of the city government . . . [and] became a catalyst for Mexico City's citizens to do something about this political situation and to actively recover urban accountability, justice, and dignity' (p. 270). Many of the organizers who developed leadership skills during these movements became an important constituency who helped elect progressive city officials that promised to increase citizen participation in the political processes of Mexico City. Additionally, the government's attention to restoring the 'macroeconomic standing' (p. 264) of the city and country - i.e. rebuilding high-profile buildings and institutions and accepting World Bank loans for long-term infrastructure projects - rather than to addressing immediate humanitarian needs, called the entire logic of Mexico's political economy into question by ordinary residents.

\section{New Orleans Recovery in Comparison}

Scholars have acknowledged that in cities in the 'developing' world, informal grassroots planning not only occurs, but such planning is actually more feasible because of the minimal attention to these communities paid by the state. In such context, Miraftab writes that 'the informality of the third world can be seen as a victory of people's will to exercise their right to the city' (2007, p. 115). However, this insurgent informality that often 
characterizes planning process in cities in the 'global south' can also be relevant in US cities. As our review of active citizenship in pre-Katrina New Orleans suggests, this informality is a pertinent context for understanding the grassroots sociopolitical sphere of working-class (and predominantly African-American) neighbourhoods in New Orleans. For instance, some planners have even been calling for a planning process that would let certain areas of the city 'opt out' of the bureaucratized planning process so that they can 'contract out' of the American planning system in which the state raises standards 'to the point where it is so costly and complicated to build that only the state can provide affordable housing' (Duany, 2007).

The autonomous neighbourhood-based planning efforts in New Orleans have accomplished significant feats of reconstruction, but could they be 'unleashed' and transformed into a broader and longer-term democratization of the city? According to Villavaso (2006), one of the top citywide planners leading the UNOP effort,

Katrina has re-energized the city into this frenzy of neighborhood-based planning . . . but I don't think it's going to lead to any quick changes. I think that those are all good ideas [to make fundamental reforms] but they're a long time coming. I don't think the current good news about civic participation in planning translates into those larger systemic changes in governance.

Yet, recent elections and formal democratic efforts suggest cautious optimism. Reform-minded activists placed a constitutional amendment on the ballot to consolidate the seven elected property assessors into one professional office; in November 2006 voters passed the measure overwhelmingly - 'the latest and most visible in a string of post-Katrina efforts aimed at overhauling the city's antiquated political machinery' (Russell, 2006). Also, after the local elected levee boards came under intense criticism for their neglect of the levees, voters overwhelmingly approved a constitutional amendment to consolidate the 20 'balkanized' levee boards into two districts (one on each bank) to coordinate the maintenance and governance of the Mississippi River levee system throughout the metro area with professionally trained appointees (Donze, 2006). The support averaged about $80 \%$ state wide, with even greater support in parishes hardest hit by Katrina, as high as $94 \%$ in Orleans Parish.

Signs of transformation have not been limited to the electoral realm. In January 2007, a group of housing activists and former residents broke into the St Bernard housing project - closed and gated by HUD since Katrina - 
to clean the mildly damaged apartments and restore them as decent affordable housing. HUD officials stood by helplessly as dozens of residents stormed the gates and began gutting and painting the apartments (Hamilton, 2007). And a contingent of community leaders from the New Orleans Survivor's Committee recently travelled to Venezuela to learn from that country's consejos comunales (community councils), which are a part of the Venezuelan government's national planning strategy that decentralizes, democratizes and funds planning efforts at the neighbourhood level (Iraza'bal \& Foley, in press). Indeed, this latent but uncertain potential for broader democratic transformation was captured in interviews with one community-based planner who heads the non-profit Neighborhood Housing Services, telling us 15 months after Katrina, 'What's going on right now with civic participation in New Orleans is almost revolutionary' (Andersen, 2006b). Yet, the operative word here is almost, for it seems that despite the 'revolutionary' potential of grassroots planning efforts, and hopeful reforms, at least two critical factors are impeding a fuller transformation.

These two factors are the continued impacts of the diaspora and the slow pace of infrastructure recovery and basic services, which are closely interrelated. With the city still under half of its pre-Katrina population, and entire neighbourhoods still abandoned and/or without telephone services and other utilities, the prospects for social transformation are limited. As in any effective social process, there must be a critical mass of people to participate. In the disaster recovery cases mentioned earlier, despite the catastrophic levels of damage, most survivors were still around to participate in the recovery efforts. As Campanella writes in his comparison of New Orleans to the Mexico City recovery mentioned above, "The geographic dispersal [of New Orleanians after hurricane Katrina] makes coordinated grassroots efforts exceedingly difficult. It will be hard to mount a campaign of the sort that helped reform Mexico City when the potential coalition is scattered across the United States with little means of communicating with one another' (2006, p. 144). While some sociopolitical conditions in Mexico City and Golcuk were similar to that of New Orleans, the postdisaster material conditions in New Orleans are significantly different in at least one prominent regard. In the former cases, even after the loss of lives and people who fled the city, a critical mass of residents remained and made recovery efforts possible. Conversely, the residents of New Orleans cannot participate in socially transformative planning when there is no critical mass of people there to engage in this sociopolitical process, and when those that are there are swamped with struggles for basic services and even survival of their neighbourhoods.

Residents are of course less likely to return if there are no services, or if, 
as in the earlier case of public housing residents, the government intentionally shuts residents out of their homes. But even middle-and upper-class homeowners are finding it exceedingly difficult to return to their homes. As of November 2006, only 28 of the 77,700 applicants to the Road Home programme to help finance critical home improvements have had cheques delivered - 15 months after the disaster (Andersen, 2006a). These factors of recovery loom large when considering prospects for socially transformative planning in New Orleans. When restoring energy, getting fresh water, and finding a grocery store are still citywide challenges, there is little time or opportunity to advocate more systemic changes. As Campanella wrote about the resilience of New Orleans, 'A city is only as resilient as its citizens. New Orleans' future as a robust and inclusive metropolis rests in large part upon the decision of thousands of evacuee families to come home and participate in the recovery process' (2006, p. 145).

For instance, of the four stages of activities that characterize disaster recovery as outlined by Hass et al. (1977; see Table 1), New Orleans has yet to meet a single one as of March 2007.

A more tailored timeline of the New Orleans' recovery was developed by New Orleans-based scholars (Kates et al., 2006), which places the city's experience in line with typical disaster recovery schedules, when accounting for the extent of the damage, the extensive outmigration, the lack of recovery dollars available/ given, and the near-stagnant local recovery planning process (see Figure 4). Yet whether or not the New Orleans recovery is occurring at a rate consistent with formal scientific projections, any resident will surely say it is happening far too slow. 
TABLE 1. New Orleans' Rate of Recovery in Comparison to Hass et al.'s model

Hass et al. model ${ }^{1}$ New Orleans

Provision of emergency measures (removal of debris, provision of housing, search and rescue) Restoration of public services (electricity, water and telephone) Replacement or reconstruction of capital stock to predisaster levels Initiation of reconstruction that involves economic growth and development

1 - 2 weeks 10 - 20 weeks *100 weeks 500 p weeks Ongoing (76 p weeks) Ongoing (76 p weeks) Ongoing (76 p weeks) Ongoing; official plans for recovery released 76 weeks after storm

${ }^{1}$ This model has been challenged on several grounds, such as that it does not address the structural inequities in some societies, class interests, time-consuming political decision making, inadequate resources, inaccurate appraisals of the extent of the damage, intense pressure by citizens to rebuild quickly, and 'multiple and conflicting preferences of afflicted groups' (Berke \& Beatley, 1997). All of these conditions apply to the recovery efforts in New Orleans.

The trajectory of recovery of New Orleans also illuminates the limits of grassroots planning in such catastrophic circumstances, and suggests that only larger and more comprehensive efforts, such as those possible for government(s), can create the conditions under which the grassroots efforts may organize meaningfully and effectively. Grassroots planning might be able to get a neighbourhood cycle path, several dozen houses gutted and a new cooperative grocery, but a recovery effort this large necessitates more than any community-based organization can possibly achieve. Neighbourhood groups can't rebuild the levees, restore energy citywide or fund a transit system. 'In contrast to conservative ideology, the Katrina disaster reveals how much we need government to provide things that individuals and the private sector cannot' (Dreier, 2006, p. 17). As CBNO president Keith Twitchell (2006) put it, "The neighborhoods are planning away, but without direction [from higher levels of government], then the process can have an awful lot of futility.' 


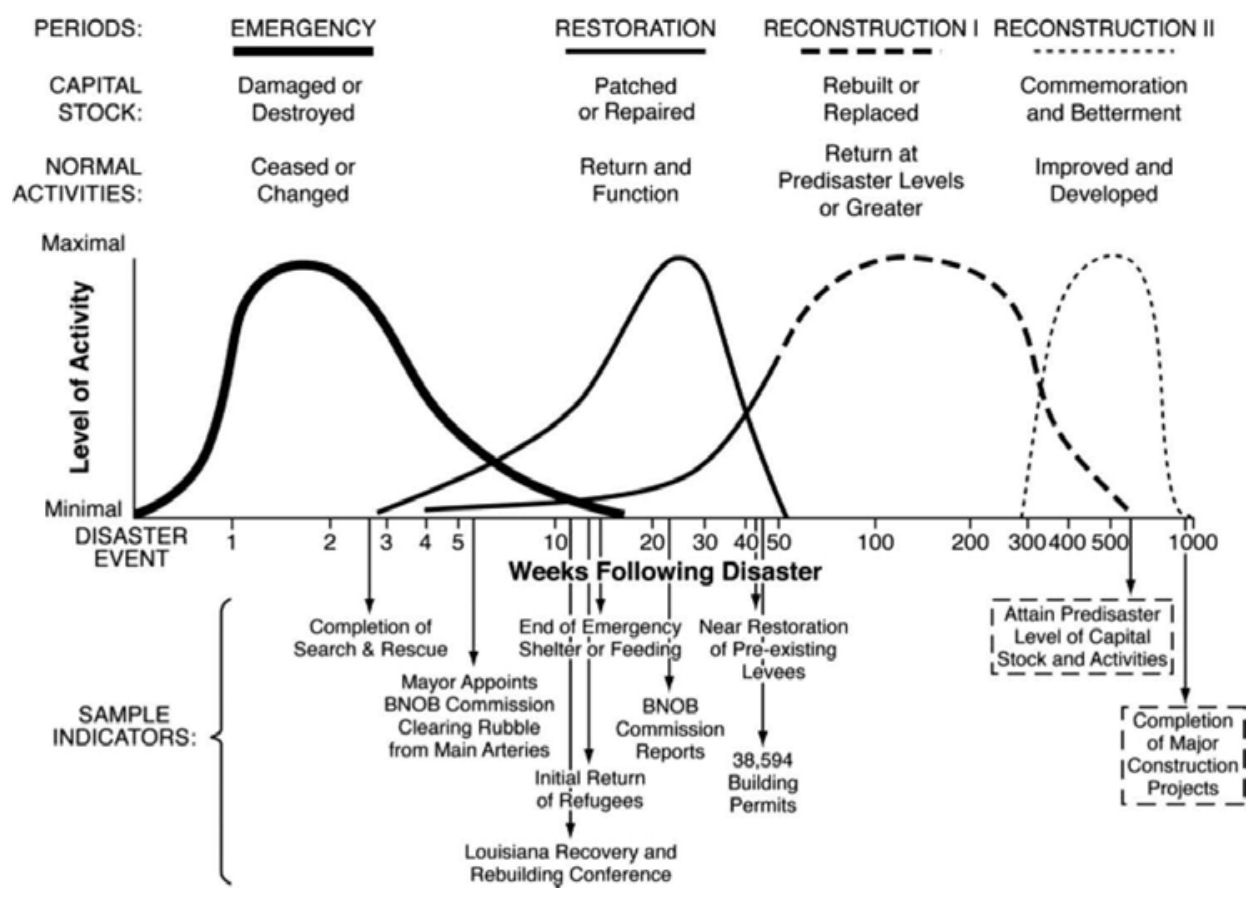

FIGURE 4. New Orleans rate of recovery factoring post-Katrina conditions (Katesetal.,2006).

As of March 2007, the City had just completed its (at least) third attempt at generating a citywide recovery plan, the UNOP, which will play a critical role in demonstrating sufficient preparation for receipt of federal reconstruction dollars. Although the process was relatively decentralized and democratic, within weeks the city's top policy watchdog group criticized it vigorously, calling it a disappointing 'continuation of the indecisive and confusing approach that has characterized New Orleans' recovery for a year and a half' and that 'the problems are so fundamental that they cannot be addressed through minor adjustments' (BGR, 2007, p. 1). These problems in the planning process continue to delay the recovery of the city and the return of its people, particularly the working-class and African-American neighbourhoods that are the most politically marginalized: 
One year after Katrina, the unified neighborhood planning process, envisioned by the city and the state, has barely begun. Some neighborhoods had begun their own planning process; other neighborhoods had professional assistance provided separately by the mayor and the city council. It has taken 10 months for the mayor, city council, and civic leaders to agree on a unified planning process with professional assistance for 73 neighborhoods and on the preparation of a citywide infrastructure plan. Underlying the fits and starts in neighborhood planning has been the reconstruction approach of various planning consultants to rebuild the "high ground first damaged areas maybe' and its conflict with the most important equity issue - the rebuilding of pre-Katrina African-American neighbourhoods (Kates et al., 2006, p. 14656).

The plans that many of the neighbourhoods developed autonomously did in fact guide the UNOP plans - either as advisory or by being absorbed altogether into the official plans. Yet, despite this 'bottom up' role that the neighbourhoods have played in the formal planning process, the informal recovery efforts continue because very few New Orleanians have faith that the formal processes will be equitable or even functional (see Figure 5). Community design centres, public housing coalitions, anarchist healthcare centres, non-profit grassroots 'house gutting' organizations, churches, neighbourhood federations, and other community-based efforts continue to operate as de facto planning institutions that are more effective in meeting the immediate needs of residents - those living in New Orleans and those still trying to get back home.

\section{Conclusions and Recommendations for Planners and Policy-makers}

Despite the unprecedented abundance of grassroots planning in New Orleans post-Katrina, the prospects for broader democratic transformation in the city are hopeful but limited, given the slow pace of infrastructure recovery and the protracted effects of the diaspora. Electoral reforms have been noteworthy but modest, and whole sections of the city are lifeless, despite residents eagerly trying to get home. Those that have made it home struggle with basic lack of services. Life in New Orleans, for now at least, seems simply a matter of survival.

Yet the case studies presented from 'third world' contexts suggest that disasters can also trigger a broadening of political consciousness beyond an exclusive attention to material concerns, exposing contradictions and failures in the overall political economy, and pushing for reforms. And we believe that the autonomous, informal mutual aid societies and their symbiotic street celebration extensions reflect a strong inclination and 
ability for collective action, an auspicious demonstration of the possibilities of grassroots celebratory democracy in New Orleans. 


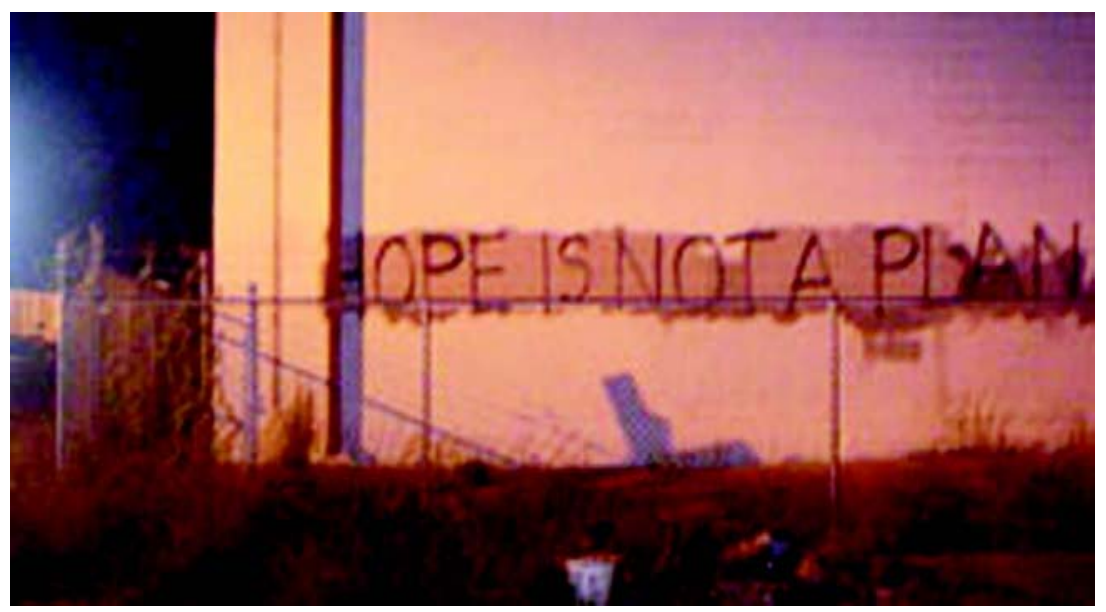

FIGURE 5. Graffiti on a wall in the 9th Ward taken in August 2006, one year after Hurricane Katrina (photo by Jason Neville).

While we cannot at this point conclude that the neighbourhood planning organizations have the capacity to realize more socially transformative goals, we believe that certain decisive actions taken by local planners and policy-makers involved in the recovery effort could help facilitate these processes. These include:

Immediately open and restore pre-Katrina public housing complexes, most of which were only mildly damaged. This will facilitate the return of crucial and politically disenfranchised working-class residents, and allow them to participate in the recovery efforts personally. More generally, the city must proactively facilitate the return of residents of all income levels. For instance, an aggressive city residential reconstruction effort would provide not only urgently needed housing, but also offer training and meaningful work to returning residents.

Institutionalize the organizational framework of the Unified New Orleans Plan by permanently incorporating community-based planning with coordinated citywide infrastructure planning. In doing so, planners can help formalize neighbourhood-level decision making without bureaucratically bludgeoning the democratic instincts and empowered participation of residents.

- Formalize citizen participation in the planning process. Recovery planning czar Ed Blakely's recent plan for rebuilding neighbourhoods in viable clusters is a responsible and democratic rebuilding strategy that many residents support - even those that may be forced to relocate. This could have been suggested from the beginning of the recovery process weeks after the storm. A formal and legitimate 
citizen participation programme will help resolve many of the tensions regarding the still-looming 'Where to rebuild?' question - and other tough decisions - by facilitating trust and collaboration between residents and planners.

Allow flexibility in the design of building codes to support the continuity of traditional New Orleanian home-building trades. This would enable working-class families to rebuild affordably. It would also be more consistent with the Caribbean rim culture of New Orleans that is artisan and community oriented in nature. This 'opting out' of the American planning system might include 'basic codes, geographic areas where they would apply, and building techniques that allow affordable piece-by-piece building' (Duany, 2007).

Regionalize planning efforts in Jefferson, St Bernard, Plaquemines and St Tammany Parishes, and eventually to all of Southeast Louisiana. With consolidation of levee boards and other balkanized institutions gaining overwhelming support, now is the time to coordinate regional planning in general, to enhance ecological, infrastructural and democratic institutions.

Aggressively restore basic infrastructure without any further delay. While a 'citizens revolution' can make some socially transformative gains in pockets of the city - however inspiring - the long-term recovery of the region is dependent on leadership from the 'top' to aggressively generate affordable housing; shore up the levees; build ecologically sustainable storm water protection; create a realistic rebuilding strategy that inspires confidence, certainty and clarity to returning residents and businesses; and fosters regional cooperation. The recovery must be then, at once 'top down' to create infrastructure(s) capable of sustaining and welcoming residents and businesses, as well as 'bottom up' in which local communities are able to develop autonomous planning strategies that are effectively woven into the larger process.

. Recognize the inherent limitations of our economic and political system and work to make progressive change at levels beyond the local or neighbourhood level. Only institutions with the size, clout and resources as the state and federal governments can leverage the funding and capacity for many of the large-scale infrastructural improvements necessary to permit and encourage the right of return for all residents. Planners committed to neighbourhood return must also therefore work to change state and federal policies to meet that goal, such as establishment of public housing, aggressive rebuilding of coastal wetlands etc. Furthermore, the 'free market' cannot and/or will 
not address many needs of working-class and working poor residents. Planners must not deny the inherently political nature of their profession, and should aggressively and responsibly advocate for state and national policies that will enable the most equitable and sustainable planning possible.

In helping progress along the aforementioned dimensions, professional planners would not dictate authoritatively the terms of recovery, but do what planners have the potential to do best: facilitate the democratic and community-based planning of the residents themselves, on their own terms, whether in New Orleans or elsewhere.

\section{Acknowledgements}

The authors would like to thank the resident-planners of New Orleans for their insights and assistance, and to dedicate this article to their inspirational efforts to rebuild New Orleans.

\section{Notes}

1 Cannizaro, a member of President W. Bush's elite class of 221 'Rangers' for helping raise over $\$ 200,000$ in the 2004 election cycle, also served as Co-Chair of the Land Use Committee of the Mayor's BNOB. $2 \quad$ Like other city agencies, the City Planning Commission suffered tremendous lay-offs in the months after Katrina. The CPC's staff, already 'barely adequate', was reduced by two-thirds to six planners (Eggler, 2005).

3 Second line parades are typically spontaneous (although sometimes briefly anticipated) street celebrations hosted by the dozens of Social Aid and Pleasure Clubs around New Orleans, usually with brass band, drinking, singing and a permeable boundary between participant and observer.

$4 \quad$ The term 'Jim Crow' refers to the period in the Southern United States after Civil War Reconstruction in which slavery was outlawed but de jure segregation of whites and blacks continued in the form of legalized segregation. These 'Jim Crow' laws were challenged in the Civil Rights struggle of the 1960s, which sought to fully grant African-Americans the constitutional rights that white Americans enjoyed. 


\section{References}

American Planning Association's New Orleans Planning Assessment Team (2005) Charting the Course for Rebuilding a Great American City: An Assessment of the Planning Function in Post-Katrina New Orleans (New Orleans, American Planning Association).

Andersen, E. (2006a) Faster work vowed on grants, Times-Picayune, 16 November. Andersen, L. (2006b) Interviewed by Author, 22 December.

Baricos, P. (2006) Interviewed by Author, 29 March. Beard, V. (2002) Covert planning for social transformation in Indonesia, Journal of Planning Education and Research, 22, pp. 15 - 25.

Berke, P. \& Beatley, T. (1997) After the Hurricane: Linking Recovery to Sustainable Development in the Caribbean (Baltimore, Johns Hopkins University Press).

Bolin, R. \& Stanford, L. (1998) The Northridge Earthquake: Communitybased approaches to unmet recovery needs, Disasters, 22(1), pp. 21 38.

Breunlin, R. \& Regis, H. (2006) Putting the Ninth Ward on the map: Race, place, and transformation in desire, New Orleans, The American Anthropologist, 108(4), p. 747.

Bureau of Government Research (2003) Runaway Discretion: Land Use Decision Making in New Orleans (New Orleans, Bureau of Government Research).

Bureau of Government Research (2007) Not Ready for Primetime: An Analysis of the UNOP Citywide Plan (New Orleans, Bureau of Government Research).

Burns, P. \& Thomas, M. (2006) The failure of the nonregime: How Katrina exposed New Orleans as a regimeless city, Urban Affairs Review, 41(4), pp. $517-527$.

Campanella, T. (2006) Urban resilience and the recovery of New Orleans, Journal of the American Planning Association, 72(2), pp. 141 - 146.

Cornwall, A. (2002) Locating citizen participation, IDS Bulletin, 33(2), pp. $49-58$.

Davis, D. (2005) Reverberations: Mexico City's 1985 earthquake and the transformation of the capital, in: L. J. Vale \& T. Campanella (Eds) The Resilient City: How Modern Cities Recover from Disaster, pp. 255 - 280 (Oxford, Oxford University Press).

Davis, J. D. (2002) Religious groups joined forces to help Hurricane Andrew's victims, South Florida Sun Sentinel, 24 August.

Donze, F. (2006) Voters merge levee boards: Support strongest where effect greatest, Times-Picayune, 1 October.

Dreier, P. (2006) Katrina and power in America, Urban Affairs Review, 41(4), pp. $1-22$.

Duany, A. (2007) Restoring the real New Orleans: How do we save the Crescent City? Re-create the unique building culture that spawned it, Metropolis Magazine, February. New York. Available at http:// 
www.metropolismag.com/cda/story.php?artid $1 / 42510$ (accessed 14 February 2007).

Eggler, B. (2000a) Panel to devise blueprint for better NO: Private committee sets eight-month deadline, Times-Picayune, 3 May.

Eggler, B. (2000b) Panel launches campaign for better NO: Roster filled with city's top activists, Times-Picayune, 4 May.

Eggler, B. (2005) City planners want role in rebuilding, Times Picayune, 29 October.

Foley, J. \& Lauria, M. (2000) Plans, planning and tragic choices, Planning Theory and Practice, 1(2), pp. 219 - 233.

Friedman, J. (2002) The prospect of cities (Minneapolis, University of Minnesota Press). Ganapati, E. (2005) Rising from the Rubble: Disaster Victims, Social Capital, and Public Policy - Case of Golcuk, Turkey, PhD Diss., University of Southern California.

Gibson, C. (1998) Population Division Working Paper No. 27 (US Bureau of the Census). Last revised 2 November 2000.

Gotham, K. F. (2005) Tourism gentrification: The case of New Orleans' Vieux Carre (French Quarter), Urban Studies, 42(7), pp. 1099 - 1121.

Grengs, J. (2002) Community-based planning as a source of political change: The transit equity movement of Los Angeles' Bus Riders Union, Journal of the American Planning Association, 68(2), p. 165.

Haas, J. E., Kates, R. W. \& Bowden, M. J. (1977) Reconstruction Following Disaster (Cambridge, MA, MIT Press).

Hamilton, B. (2007) Protesters take over closed complex: Activists, residents begin cleanup, Times-Picayune, 16 January.

Holston, J. (1998) Spaces of insurgent citizenship, in L. Sandercock (Ed.) Making the invisible visible: A multicultural planning history (Berkeley, CA, University of California Press).

Holston, J. (1999) Spaces of insurgent citizenship, in: J. Holston (Ed.) Cities and Citizenship (Durham, NC, Duke University Press), pp. 155 - 173.

Irazabal, C. \& Foley, J. (in press) Reflections on the Venezuelan Transition from a Capitalist Representative Democracy to a Socialist Participatory Democracy: What is a Planner to Do? Paper presented at the Planners Network Conference 2007. New Orleans.

Irazabal, C. (2008) Citizenship, democracy, and public space in Latin America, in: C. Iraza'bal (Ed.) Ordinary Places, Extraordinary Events: Citizenship, Democracy, and Public Space in Latin America (London, Routledge).

Kates, R. W., Colten, C. E., Laska, S. \& Leatherman, S. P. (2006) Reconstruction of New Orleans after Hurricane Katrina: A research perspective, Proceedings from the National Academy of Sciences of the United States of America, 103(40), pp. 14653 - 14660. Available at: www.pnas.org/cgi/doi/10.1073/pnas.0605726103 (accessed 30 August 2006).

Kearns, A. (1995) Active citizenship and local governance: Political and 
geographical dimensions, Political Geography, 14, pp. 155 - 175.

Krupa, M. (2007) Blakely expects job to take a year, Times-Picayune, 6 April.

Lang, R. E. \& Danielsen, K. A. (eds) (2006) Review roundtable: Is New Orleans a resilient city?, Journal of the American Planning Association, 72(2), pp. 245 - 257. Laska, S. B. \& Spain, D. (1979) Urban policy and planning in the wake of gentrification, Journal of the American Planning Association, 45(4), p. 523.

Lefebvre, H. (1974 [1991]) The Production of Space (Cambridge, MA, Blackwell Publishing).

Lefebvre, H. (1996) Writings on Cities, trans. E. Kofman \& E. Lebas (Oxford, Blackwell).

LeGardeur, L. (2004) Getting their ACT together, Gambit Weekly, 12 October.

Mary Queen of Vietnam (2006) Community Development Report, 28 February.

Miller, R. (2001) NO East residents step up to plate: Revitalization plan attracts a full house, Times-Picayune, 26 August.

Miraftab, F. \& Wills, S. (2005) Insurgency and spaces of active citizenship: The story of Western Cape anti-eviction campaign in South Africa, Journal of Planning Education and Research, 25, pp. 200 - 217.

Neighborhoods Planning Network. (2006) August. Available at http://www.neighborhoodsplanning.com (accessed August 2006).

New Orleans Survivor's Council (2007) New Orleans Survivor Council Turns to Venezuela for Support. March 2. Available at: http://peoplesorganizing.org/breaking_news.html\#nos (accessed 6 May 2007).

Nolan, B. (1994) Second church-based group ready to help change city, Times-Picayune, 23 October.

Nolan, B. (2006a) Making all things new: Churches find a way to rebuild homes, communities, lives, Times-Picayune, 11 June.

Nolan, B. (2006b) Broadmoor plan gets boost: $\$ 45$ million pledged in Clinton initiative, Times-Picayune, 28 September.

Nossiter, A. (2006) Bit by bit, some outlines emerge for a shaken New Orleans, New York Times, 26 August.

Pastor, M., Bullard, R., Boyce, J., Fothergill, A., Morello-Frosch, R. \& Wright, B. (2006) In the Wake of the Storm: Environment, Disaster, and Race After Katrina (New York, Russell Sage Foundation).

Pittman, C. (2002) Storm's howl fills the ears of survivors, St Petersburg Times, 18 August.

Regis, H. (1999) Second lines, minstrelsy, and the contested landscapes of New Orleans Afro-Creole Festivals, Cultural Anthropology, 14(4), pp. $472-504$

Regis, H. (2001) Blackness and the politics of memory in the New Orleans second line, The American Ethnologist, 28(4), pp. 752 - 777. 
Russell, G. (2006) New assessor system to take effect in 2010, TimesPicayune, 8 November.

Russell, G. \& Donze, F. (2006) Planners anticipate a better city, but residents must guide rebuilding, Times-Picayune, 22 January.

Simmons, A. (2006) In New Orleans, self-sufficiency is the theme, Los Angeles Times, 21 April.

Spitzer, N. (2006) Rebuilding the 'Land of Dreams' with Music, in E. L. Birch \& S. M. Wachter (Eds) Rebuilding Urban Places After Disaster: Lessons from Hurricane Katrina (Philadelphia, University of Pennsylvannia Press).

Stark, J. (2002) New building code brings cost, confusion, St Petersburg Times, 19 August.

St Petersburg Times (2002) Special Report. After the Storm: 2002, Available at: www.sptimes.com/2002/ webspecials02/andrew/ (accessed 30 August 2006).

Times-Picayune (1993) ACT shaping city's agenda, 18 January.

Twitchell, K. (2006) Interviewed by Author, 12 April.

US Census Bureau (2005) American Community Survey. Available at: www.census.gov (accessed 16 April 2007).

Villavaso, S. (2006) Interviewed by Author, 12 August.

Warner, C. (1998) Residents dislike intensive land use: Study: Quiet enclaves popular, Times-Picayune, 9 September.

Warner, C. (2006) NO planning process puts residents on edge: There's no way to tell what happens next, Times-Picayune, 31 August.

Williams, L. (2005) Under the radar: Starting over is nothing new for thousands of New Orleanians with roots in Vietnam, but many feel they are not being given a voice in the process, Times-Picayune, 27 November.

Winkert, D. (2006) Interviewed by Author, 11 August.

Young, T. (2001) Meetings on city's future overlap, Times-Picayune, 15 August. 